Síntese: Revista de Filosofia adere a uma Licença

\title{
HANS JONAS E O FIM DA TEODICEIA: CONSIDERAÇÕES SOBRE O CONCEITO DE DEUS DEPOIS DE AUSCHWITZ *
}

Hans Jonas and the End of Theodicy: Considerations on The Concept of God after Auschwitz

Wendell Evangelista Soares Lopes **

Resumo: O presente ensaio mostra como, a partir de dois eixos de argumentação, um, lógico-ontológico, e o outro, teológico, Hans Jonas, filósofo judeu-alemão, constrói um conceito de Deus que em seu cerne representa conseqüentemente uma base para a expurgação - isto é, o fim - de toda teodiceia. Como se sabe, a teodiceia sempre lançou mão de duas respostas fundamentais: a lógica da culpabilidade e a do sacrifício. Estas foram sempre respostas ao problema do mal. Mas o evento de Auschwitz romperia em definitivo com tais soluções. Não há motivos para tamanho mal, pois aí não há culpabilidade, nem mártires; trata-se de um acontecimento de magnitude única e incompreensível. Face ao horror de Auschwitz, Jonas reflete sobre um mito que ele próprio elaborara inicialmente como resposta à questão da imortalidade, mas que mais tarde ele utilizará para pensar a questão abissal da teodiceia. $O$ que Jonas extrai de seu mito, nesta nova direção, é a ideia de um Deus em vir-a-ser, sofredor, e preocupado. Do "Fundamento do ser, ou o Divino" assim pensado já não se pode dizer que seja onipotente, e uma tal imagem oferece a resposta à questão da teodiceia: de um Deus impotente não se pode mais dizer que é responsável. $O$ resultado não pode ser outro senão o non-sense de qualquer intento de condenação do Divino pela realidade do mal.

Palavras-chave: Auschwitz. Teodiceia. Conceito de Deus. Panenteísmo.

\footnotetext{
* Artigo recebido em 15/04/2020 e aprovado para publicação em 03/12/2020. .

** Professor Adjunto da Universidade Federal de Mato Grosso (UFMT).
} 
Abstract: This paper shows how from a logical ontological perspective and a theological one, the German-Jewish philosopher Hans Jonas develops a concept of God whose core provides a basis for purging - that is, for putting an end to - all theodicy. As is well known, theodicy has always resorted to three basic responses: the banality of evil, the logic of guilt and that of sacrifice. These were always answers to the problem of evil. But what happened in Auschwitz breaks definitively with those approaches. There is no reason for such evil, because in Auschwitz there was no guilt or martyrs; it was an event of incomprehensible magnitude. Faced with the horror of Auschwitz, Jonas reflects on a myth that he himself had developed initially as an answer to the question of immortality, but that he will use later to think about the abyssal question of theodicy. What Jonas draws from his myth is the idea of a God who is becoming, suffering, and caring. In this way of thinking, the Divine" can no longer be said to be omnipotent, and such an image of God provides the answer to the question of theodicy: a powerless God can no longer be said to be responsible. The result can be none other than the nonsense of condemning the divine because of the reality of evil.

Keywords: Auschwitz. Theodicy. Concept of God. Panentheism.

$\mathrm{N}$ este ensaio temos como escopo abordar o conceito de Deus que Hans Jonas desenvolve como resposta ao horror e ao silêncio das sombras que se ergueram com Auschwitz. Mais uma vez ganha cena o velho problema da teodiceia. No entanto, esse problema aparece agora com uma radicalidade incomparável. A tarefa que nos cabe é mostrar como, para Jonas, Auschwitz reivindica um repensar sobre a questão do mal em toda sua radicalidade, uma vez que as antigas respostas ao problema não se sustentam mais face ao horror que ganhou lugar com a Shoah; e como, portanto, um novo conceito de Deus se faz necessário - e também mais pertinente e autêntico - para um confronto mais acertado com aquela velha questão. Para a realização de tal tarefa, primeiro elucidaremos em que medida Auschwitz escancara a realidade do mal sob uma radicalidade jamais pensada. Depois, nos concentraremos em apresentar o conceito de Deus que Jonas desenvolve em todas suas implicações teológicas, demonstrando finalmente, como um último passo, em que sentido se estabelece a relação entre o conceito jonasiano de Deus e o fim da teodiceia propriamente. Como uma última observação metodológica, apenas ressaltamos, ainda, que é do texto "The concept of God after Auschwitz"1

\footnotetext{
${ }^{1}$ Utilizaremos a versão inglesa deste texto, feita pelo próprio Jonas (1987). A versão alemã é Der Gottesbegriff nach Auschwitz. Eine jüdische Stimme. Frankfurt am Main: Suhrkamp, 1987. Tal palestra foi publicada primeiro em Fritz Stern e Hans Jonas, Reflexionen finsterer Zeit (Tübingen: J. C. B. Mohr, 1984); ela expandiu e remodelou um artigo anterior com o mesmo título: "The Concept of God after Auschwitz", em Out of the Whirlwind, ed. A. H. Friedlander (New York: Union of American Hebrew Congregations, 1968, pp. 465-76). Já há uma tradução da obra para o português: O conceito de Deus após Auschwitz: uma voz judia. tradução Lilian Simone Godoy Fonseca. São Paulo: Paulus, 2016.
} 
que nos serviremos como referência orientadora para nosso estudo, mas que, de modo algum, se estabelece como a única fonte da análise que ora pretendemos apresentar no que tange ao conceito jonasiano de Deus, de modo que vários de seus textos serão sempre chamados a formar uma abordagem mais ampla desse conceito no interior do pensamento de Jonas como um todo.

\section{Auschwitz como Problema Radical para a Teodiceia}

De início, é preciso dizer que a questão da teodiceia é tão antiga quanto problemática, reclamando, assim, uma breve contextualização introdutória a seu respeito. Como se sabe o termo teodiceia vem da união de duas palavras gregas: thèos, que significa ser imóvel, ser perfeito, Deus; e dikaia, que significa justificação. Teodiceia seria, portanto, a justificação de Deus. Mas trata-se da justificação de Deus face a uma realidade específica: o mal. Mais diretamente, o que envolve o problema da teodiceia é exatamente o paradoxo da existência dessa realidade que é o mal, sendo ela totalmente o avesso do que Deus é, isto é, bom, e todo-poderoso. De acordo com a viva análise de Paul Ricoeur ${ }^{2}$, pode-se distinguir cinco estágios do discurso na especulação sobre o mal: o mito, a sabedoria, a gnose e a gnose anti-gnóstica, a teodiceia propriamente, e a dialética desarticulada. Para ele, só se pode falar em teodiceia propriamente quando o justificação alcança os níveis em que (1) se busca conciliar as três assertivas seguintes: Deus é todo-poderoso; Deus é bom; e o mal existe; (2) se torna apologético, no sentido de desresponsabilizar Deus da existência do mal; e (3) na medida em que se pretende não-contraditório e sistemático - como é o caso com Leibniz, o primeiro a estabelecer propriamente uma teodiceia. Não obstante, a problemática própria da teodiceia se encontra já em todos os níveis, e aí encontramos o mal pensado em suas várias facetas.

De modo geral, o mal é chamado a responder por realidades distintas como o pecado, o sofrimento e a morte. Dessas realidades dois sentidos fundamentais se levantam: no primeiro sentido, encontra-se a ideia de um mal cometido, como no caso do pecado, que a bem dizer é a tradução religiosa do que se entende por mal em termos morais. Já num segundo sentido vê-se o homem numa posição de passividade frente ao mal: trata-se do mal enquanto sofrido, como é o caso dos sofrimentos físicos e psíqui$\cos$, a experiência da miséria e finitude humanas face à temporalidade e à morte, etc. $\mathrm{O}$ mal enquanto cometido se liga à ideia de culpabilidade e condenação, e o mal sofrido, à ideia de sacrifício, martírio, o que dá ao

${ }^{2}$ RICOEUR, P. Le Mal: un défi à la philosophie et à la théologie (1986). In: Lectures 3: Aux frontières de la philosophie. SJ. Ed. Seuil, Paris, 1994, 211-233. 
homem a posição de vítima. Claro está que ambos os aspectos se misturam conforme o contorno que se lhes dê, de tal modo que o mal cometido pode levar ao mal sofrido e vice-versa.

Do confronto com o mal se levantam os próprios questionamentos sobre esse velho enigma: "o que é o mal?" - isto que seria um nível ontológico do questionamento -; em um nível genealógico: unde malum? (de onde vem o mal?); ou ainda unde malum faciamus? (de onde vem o mal que fazemos?) - que além de se remeter ao problema da genealogia do mal, toca o aspecto moral do problema do mal. Todas essas foram sempre questões que se fizeram - e se fazem - presente face à realidade do mal. As respostas tradicionais ao problema, em seus vários aspectos - ontológico, genealógico e moral -, sempre se aproximam, de modo parcial, da dificuldade que o mal impõe ao pensamento. Quando lançamos os olhos para o que elas oferecem, encontramos sempre um dos aspectos referidos sendo privilegiados. As possibilidades são basicamente quatro ${ }^{3}$ : em um primeiro sentido, o mal é co-originário com o bem - é o caso do zoroastrismo e do manequeísmo. Sob uma segunda forma, o mal pode ser pensado com o próprio fundamento da realidade, como se vê no gnosticismo, e também em Schopenhauer. Uma outra forma de se pensar seria tomar tanto o mal como o bem como algo puramente subjetivo - aqui encontramos o niilismo relativista, e anteriormente a esse último, o estoicismo, cuja ressonância é tão patente no pensamento de Nietzsche; uma última forma de se pensar o mal seria concebê-lo como uma corrupção ou degeneração do bem, como se vê na tradição judeu-cristã, em que o nome de Santo Agostinho ganha destaque na reflexão sobre o problema do mal com a ideia de pecado original. Nas três primeiras possibilidades o aspecto moral se enfraquece, ainda que se possa esboçar uma reflexão moral. De fato, essas primeiras opções sugerem mesmo um certo amoralismo, ou até mesmo um profundo imoralismo, como se vê, por exemplo, no sistema gnóstico de Carpócrates. Aí o mal em grandes linhas assume o aspecto da banalidade - ainda que não em todos os casos referidos, como no caso, por exemplo, do denso ascetismo que se pode encontrar em alguns sistemas gnósticos. Já a quarta possibilidade que destacamos privilegia o aspecto moral, ainda que não deixe de pensar os outros aspectos. Nela, principalmente, o enigma do mal sofrido permanece sem explicação, sendo apenas a culpabilidade convocada a assumir a total responsabilidade pelo drama do mal. Não obstante, a tradição judaico-cristã tem o exemplo de Jó, o justo sofredor, escolhido para ser um verdadeiro testemunho do significado de todo sacrifício que ao homem eleva à condição de santo - que não tem outro sentido senão responder ao problema do mal sofrido.

Não poderíamos oferecer uma explanação mais detalhada de todas essas linhas de reflexão sobre o mal, antes o que devemos destacar é apenas

${ }^{3}$ FONTI, Diego. Del Mal (contra toda teodicea). Nombres, n 17, dec. 2002, p. 137-150 [esp. p. 138]. 
que, em seu percurso, a teodiceia sempre lançou mão de três respostas fundamentais: a banalidade do mal, a lógica da culpabilidade e a lógica do sacrifício. Estas foram sempre respostas ao problema do mal. Mas o que Jonas tem a dizer sobre essas respostas? Elas podem realmente responder à questão radical da teodiceia? E esta última pergunta traz consigo obrigatoriamente - no nosso caso específico - uma outra questão: por que Auschwitz recoloca o problema da teodiceia? Sob quais novos aspectos, e com que radicalidade?

Para responder essas primeiras perguntas, é necessário entender primeiro que, para Jonas, "a questão de Jó foi sempre a principal questão da teodiceia" ${ }^{4}$. Mas, para ele, esta questão se divide, porém, em dois âmbitos: o primeiro, relacionado ao que seria uma teodiceia universal, enquanto resposta à presença do mal no mundo; o outro, seria o âmbito de uma teodiceia particular. Elucidemos em que sentido Auschwitz se levanta como problema radical para toda teodiceia universal que reclama o tipo de resposta que se poderia chamar de uma "banalidade do mal". A indiferença entre bem e mal, ou mesmo a supervalorização do mal frente ao bem - premissas estas próprias de todo niilismo e suas várias faces - são rebatidas por Jonas mais especificamente em sua principal obra Das Prinzip Verantwortung (1979): “a mera predicabilidade [Zusprechbarkeit] de valor aos entes [Seindes], independentemente do muito ou pouco que se encontre atualmente presente, determina já a superioridade do ser sobre o nada - ao qual absolutamente nada é predicável, nem valor nem desvalor" ${ }^{\prime \prime}$. Segundo Jonas, há, portanto, um valor absoluto do ser - isto é, de tudo o que é, existe - frente ao nada - o não-existente -, visto que o nada nem mesmo pode ser valorizado. Que exista uma finalidade do mundo e atuando no mundo - sua existência pelo menos - eis um Bem-em-si ${ }^{6}$. Ora, mas se este é o caso, por que então afirmar o valor do ser sobre o nada - retomando-se, inclusive, a questão ilustre: "por que há algo e não antes o nada?" -, se é certo que há antes o ser do que o nada, e assim sempre o será? Resposta:

"antes podia-se dizer Fiat justitia, pereat mundus, 'que se faça justiça mesmo que o mundo pereça' - onde 'mundo', claro, significava o enclave renovável no todo imperecível; nem retoricamente o mesmo pode ser mais afirmado, na medida em que o perecer do todo se tornou através das ações [tecnológicas] do homem... uma possibilidade real"7.

\footnotetext{
${ }^{4}$ JONAS, Hans. The Concept of God after Auschwit, p. 2.

${ }_{5}^{5}$ JONAS, Hans. Das Prinzip Verantwortung: Versuch einer Ethik für die technologische Zivilisation. Frankfurt am Main: Suhrkamp, 1984, p. 100.

${ }^{6}$ A este respeito, diz B. Sève, que, para Jonas "há uma objetividade do Bem; Jonas toma o partido de Platão contra Kant: o Bem é real, o Bem é causa" (SÈVE, Bernard. Hans Jonas et l'Éthique de la Responsabilité. Esprit, novembre, 1990, p. 72-88 [esp. p. 81].

${ }^{7}$ JONAS, Hans. Das Prinzip Verantwortung: op. cit., p. 33.
} 
Eis aí um primeiro significado radical desse acontecimento que atende pelo nome "Auschwitz": ele é um símbolo do mal, pois, antes de tudo, explicita as consequências nefastas do potencial atômico-apocalíptico do homem. Para Jonas, Auschwitz é a marca da desumanização, não só porque ali todo o resquício de dignidade foi retirado dos que morreram, mas também porque representou a expressão direta do risco que o poderio tecnológico humano coloca para a humanidade, onde até mesmo a própria natureza em sua totalidade se vê ameaçada. É em função do que ocorreu em Auschwitz que, no livro Materie, Geist und Schöpfung (1988), Jonas ataca as pretensões metafísicas como as de Aristóteles, Hegel, Teilhard de Chardin, Leibniz, e Whitehead. Diz ele:

“A objeção substancial (não apenas formal-epistemológica) comum que se pode dirigir a todas essas ficções da razão especulativa é a de que elas nos contam sobre as auto-garantidas success stories do Ser, que não podem fracassar. E todas essas histórias de sucesso, apoteose do que é, parecem-me grandes metafísicas do ser, das quais conheci a partir da história do pensamento: seja no sentido da perfeição estático-permanente, como o deus sive natura de Spinoza, ou o logos universal dos estóicos, ou o universo teleológico de Aristóteles, eternamente movido pelo motor imóvel; seja no sentido de uma dinâmica escatológico-perfectível, como em Hegel"8.

Em todas as metafísicas referidas acima, o fator perfectível do ser inviabiliza uma reflexão autêntica da experiência do mal, tornando-o mesmo uma banalidade: um momento irrisório e vazio da perfeição eterna do ser. É o que bem percebe Caterina Rea ao afirmar que em Jonas se explicita uma clara indisposição contra "uma das tentações antigas da tradição filosófica, aquela de reduzir o mal... a um momento necessário do desenvolvimento do Todo, a uma simples etapa negativa e como tal destinada a ser superada" . De fato, a recusa da teodiceia em Jonas - como se confirmará ao fim de nosso trabalho -, seria uma espécie de sucedâneo dessa recusa do panteísmo, que aos olhos de nosso filósofo poderia muito bem ser interpretado como um "pandiabolismo"10. Assim, como bem explicita Vittorio Hösle, o que Jonas busca é rechaçar o pré-determinismo, porque "ele crê que seja incerto que o mundo possa ou não levar a cabo com êxito a aventura divina iniciada nele"11. A confirmação disso encontra-se já em Das Prinzip Verantwortung:

"Apenas com a superioridade do pensamento e com o poder que ele tornou possível para a civilização técnica, foi possível que uma forma de vida, 'o homem', fosse capaz de ameaçar todas as demais formas (e com isso a

\footnotetext{
${ }^{8}$ JONAS, Hans. Materie, Geist und Schöpfung. Frankfurt: Suhrkamp, 1988, p. 54.

${ }^{9}$ REA, Caterina. Retrait de Dieu et question du mal. Une lecture éthique du mythe de Hans Jonas. Revue Philosophique de Louvain 100(3), 2002, p. 527-548 [esp. p. 533].

${ }^{10}$ JONAS, Hans. Materie, Geist und Schöpfung. Op. cit., p. 47.

${ }^{11}$ HÖSLE, Vittorio. Grandezas y Limites de la Filosofia Moral de Kant. In: El tercer mundo como problema filosofico y otros ensayos. Bogota: CEJA, 2003, p. 69-95 [esp. p. 93].
} 
si mesma também). A 'natureza' não poderia ter corrido um risco maior do que ter deixado o homem emergir, e toda ideia 'aristotélica' de uma teleologia da 'Natureza' (phisis) como um todo que atende a si mesma e automaticamente assegura a harmonia dos muitos propósitos em um fica refutada por esta última situação, algo que nem mesmo Aristóteles poderia ter suspeitado" 12 .

Em vista de tais constatações cosmológicas - e também antropológicas -, enquanto não apontam outra coisa senão o risco da aventura do mundo, o que se deve entender é o fato de que a busca cosmogônica de Jonas "não se vinculou por casualidade ao nome de 'Auschwitz"'13. Auschwitz seria, assim, um marco para a incessante busca jonasiana de refutação do niilismo, afirmando-se mesmo como um escândalo inigualável para toda e qualquer intenção teórica de pensar o mal como uma banalidade. Auschwitz é um símbolo incomparável do mal radical na medida em que representa a possibilidade real do anti-tipo do ser enquanto Bem-em-si.

Mas esse não é o único símbolo que Auschwitz vincula. Pois, para Jonas, Auschwitz foi também "um acontecimento teológico"14. E como tal, ele se impõe como um rompimento com as outras duas respostas da teodiceia - a saber, a culpabilidade e o sacrifício. Temos agora que mostrar, então, por que Jonas simplesmente não as pode aceitar. É aqui que encontramos o problema específico que Auschwitz levanta para uma teodiceia particular, ou para adiantar, para aquilo que se refere à "exacerbação [do problema da teodiceia] pelo enigma da eleição" ${ }^{15}$ - e essa distinção, como veremos, não é pouco decisiva para o problema, mas antes aponta para um dos grandes aspectos da radicalidade do mal que se fez marcante em Auschwitz. Jonas traça mesmo três momentos que essa teodiceia percorre. Partindo de seu primeiro aspecto, que não recorre senão à lógica da culpabilidade, o mal é castigo pela infidelidade do povo de Israel face à sua aliança com Deus. Nesta perspectiva, o mal seria entendido como o castigo a uma esposa infiel. Mas uma vez restabelecida a fidelidade, é a ideia de "testemunho" que então ganha cena, legando o conceito de mártir à posteridade. Um último passo à frente e o que se viu foi que "comunidades inteiras na Idade Média encontraram sua morte pela espada e pelo fogo com o Sh'ma Jisrael, a confissão da unidade de Deus, em seus lábios"16. E os sacrifícios que sempre sofreram foram tomados também sempre como um chamado à santidade e à espera pelo Messias redentor a advir: "as vítimas eram chamadas 'santas"'17. Para Jonas, entretanto, o evento de Auschwitz rompe

\footnotetext{
${ }^{12}$ JONAS, Hans. Das Prinzip Verantwortung: Versuch einer Ethik für die technologische Zivilisation. Frankfurt am Main: Suhrkamp, 1984, p. 247.

${ }_{13}^{13}$ JONAS, Hans. Materie, Geist und Schöpfung. Op. cit., p. 54.

${ }^{14}$ Idem.

${ }^{15}$ JONAS, Hans. The Concept of God after Auschwitz. Op. cit., p. 2.

16 Idem.

${ }^{17}$ Idem.
} 
com essas respostas. Por quê? Porque, de Auschwitz, há que se dizer: "nem fidelidade ou infidelidade, crença ou descrença, nem culpa ou punição, nem julgamento, testemunho ou esperança messiânica... De tudo isto, Auschwitz, que também devorou crianças e bebês, nada sabia"18. Quer isto dizer, trata-se de um mal sem motivos, e por isso mesmo um acontecimento de magnitude única e incompreensível. As vítimas ali não morreram por amor a fé, nem por causa de sua fé, ou qualquer outra coisa. Ali apenas

"A desumanização por total degradação e miséria precedeu suas mortes, nenhum lugar de dignidade foi deixado aos destinados à solução final, dificilmente um traço disso foi achado nos esqueléticos fantasmas sobreviventes liberados dos campos. E não obstante, paradoxo dos paradoxos: era o antigo povo da 'aliança'"19.

Levinas, outro filósofo judeu de grande poder intelectual, e também profundo conhecedor das questões judaicas, explicita em termos parecidos o sentido do horror que a shoah - esse "paradoxo dos paradoxos" - representou para o povo judeu:

“verbo anti-semita sem par, és injúria como as demais injúrias? Verbo exterminador pelo qual o Bem que se gloria de Ser regressa à irrealidade e, encolhido, se agrega no fundo de uma subjetividade, como ideia angustiante e assustadora. Verbo que revela à humanidade inteira, por meio de um povo - eleito para fazê-la entender -, uma desolação niilista que nenhum outro discurso conseguiria sugerir. Esta eleição é, sem dúvida, uma desgraça" ${ }^{20}$.

No texto de Jonas, também encontramos uma conclusão idêntica: Auschwitz - afirma ele - é "a mais monstruosa inversão da eleição em maldição, que desafiou toda possível significação" ${ }^{21}$. Auschwitz não conheceu nem santos, nem mártires; a desumanização foi o que se presenciou com horror ali. A culpa também não poderia ser reclamada das crianças e bebês que foram tragadas por essa máquina, que mais do que qualquer outra coisa, encerra o Bem em um lugar de irrealidade, e corteja a desolação niilista ao apregoar o vazio de um mundo inóspito, frio, e sem sentido. E, a Jonas pesa admitir: "Deus permite isto acontecer" ${ }^{22}$. O problema aumenta na medida em que se entende, como destaca Jonas, que há uma diferença entre o cristão e o judeu quando se pergunta sobre esse Deus que permite. Porque, para o cristão, este mundo é a própria causa do mal, haja vista a entrada do pecado no mundo. Já para o judeu, a imanência é o lugar da criação, da justiça e da redenção divina. Deus é mais propriamente "o Senhor da História, e a esse respeito "Auschwitz" coloca, até mesmo para o crente, todo conceito tradicional de Deus em questão" ${ }^{23}$. Que o mal aconteça é já

\footnotetext{
${ }^{18}$ Idem, p. 3.

${ }^{19}$ Idem.

${ }^{20}$ LEVINAS, Emanuel. Sin Nombre. Diálogo Filosófico 43, 1999, p. 27-30 [esp. p. 30].

${ }^{21}$ JONAS, Hans. The Concept of God after Auschwitz. Op. cit., p. 3.

${ }^{22}$ Idem.

${ }^{23}$ Idem.
} 
algo duro; que aconteça de um modo brutal e desumanizador justamente ao povo escolhido, ao povo da aliança, para quem Deus é o "Senhor da história", eis o símbolo do insuportável. E isto é um aspecto radical que só o judeu pode compreender de maneira plena.

Aqui podemos resumir o símbolo-duplo que representa Auschwitz: ele é o evento radical que, por um lado, escancara o risco total da aventura do mundo, e, por outro, escancara a exacerbação do mal frente ao enigma da eleição. Eis então por que Jonas não pode se calar diante de tal acontecimento, que levara consigo também sua própria mãe. E nesse momento em que o silêncio já não pode se calar, que a questão se levanta inevitavelmente para Jonas: que Deus pode permitir um mal tão assombroso e horrendo como Auschwitz? Como um símbolo-duplo do mal em toda sua radicalidade - radicalidade que é ainda mais radical para todo judeu -, Auschwitz obriga um repensar sobre o conceito de Deus, para que esse ainda possa ser pensável.

\section{O Conceito de Deus depois de Auschwitz}

Do que dissemos, percebe-se que é diante do problema radical que Auschwitz levanta para toda teodiceia que Jonas se vê convocado a repensar o conceito de Deus. Mas pensar Deus implica questionar-se sempre sobre a própria possibilidade do conhecimento de Deus. Quanto a isso, Jonas diz: "o que tenho a oferecer é um pedaço de teologia assumidamente especulativa" 24 . Ele assume, portanto, o veto cognitivo kantiano acerca da meditação metafísica (em especial sobre a teologia natural), mas de forma alguma consente com a completa abstenção e renúncia que exige o positivismo lógico de seu tempo. Desse modo, Jonas pode defender que aquele que não consentiu com a censura positivista "está livre, portanto, para trabalhar o conceito de Deus, mesmo sabendo que não existe prova da existência de Deus, como uma tarefa do entendimento, não do conhecimento; e tal trabalho é filosófico quando mantém o rigor do conceito e sua conexão com o universo dos conceitos" 25 .

Que seja um trabalho com conceitos, eis um dado importante a ser considerado, pois esse "pedaço de teologia especulativa" tem certamente mais embasamento e amplitude do que se possa pensar à primeira vista. Em uma conferência sobre a influência de Heidegger no pensamento teológico contemporâneo, conferência esta intitulada "Heidegger and theology" (1964), Jonas aproveita para esboçar sua própria contribuição para a reflexão do

${ }^{24}$ Idem, p. 1.

${ }^{25}$ Idem, p. 2. 
conhecimento de Deus. Ele se embate com Heidegger ${ }^{26}$, e também com Bultmann, famoso teólogo protestante, que fora, inclusive, seu professor em Marburg. O mais destacado lampejo de Bultmann, cuja teologia busca seu fundamento no Heidegger de Sein und Zeit, encontra-se na ideia de "desmitologização"27. O que nega Bultmann com essa ideia é o valor da linguagem mítica da Bíblia para a objetivação da ação de Deus - o mito é mesmo aí negado em seu valor de significação ${ }^{28}$. E é justamente neste ponto que Jonas se confronta com Bultmann, pois ainda que concorde com o teólogo protestante ao pensar que as categorias existenciais de Heidegger sejam mais adequadas para a compreensão do homem do que os conceitos mitológicos do novo testamento, o mesmo procedimento desmitologizante não pode se aplicar a Deus, ou ao Divino. Antes, onde o homem faz a experiência do divino, diz Jonas em "Heidegger and Theology", deve cessar toda pretensão e competência da linguagem conceitual e o "discurso simbólico deve começar", pois "o paradoxo final é melhor protegido pelos símbolos do mito" ${ }^{29}$. Para Jonas, se bem se percebe, a linguagem que se deve buscar na objetivação da experiência de Deus não deve se erguer senão a partir de uma racionalidade mítica. Sim, porque os mitos também têm razões, e ademais, salvam a experiência do inefável, este desconcer-

\footnotetext{
${ }^{26}$ Aqui, não cabe avaliar a validade da crítica de Jonas ao pensamento heideggeriano. Para uma apreciação de tal problema cf. RICHARDSON, William J. Heidegger and God - and Professor Jonas. Thought 40, n 156, 1965, p. 13-40; SCOTT, Charles R. Heidegger reconsidered: a response to professor Jonas. Harvard Theological Review, 59:2 (1966): p. 175-185; e também JONAS, Hans. Erinnerungen: Nach Gesprächen mit Rachel Salamander. Frankfurt am Main: Insel Verlag, 2003., p. 303-309).

${ }^{27}$ É preciso destacar que este conceito de "desmitologização" (Entmythologisierung), que o teólogo protestante tornou famoso em 1941 (cf. BULTMANN, Rudolf. (1960 [1941]). Neues Testament und Mythologie. Das Problem der Entmythologisierung der neutestamentlichen Verkündigung (1941). In: BARTSCH, H.-W. (Hrsg.): Kerygma und Mythos, Band 1, 4. Auflage. Reich, Hamburg 1960) não era senão um conceito originalmente criado, com dez anos de antecedência, pelo próprio Jonas, sendo utilizado por ele no campo da história das religiões e do gnosticismo, e tendo o sentido de uma verdadeira "tarefa hermenêutica" (JONAS, Hans. Wissenschaft als persönliches Erlebnis. Göttingen: Vandenhoeck \& Ruprecht, 1987, p. 17). Esta hermenêutica da desmitologização era em Jonas um método que visava interpretar mitos e dogmas religiosos a partir de experiências existenciais que se encontram no fundo daqueles, e cujo reconhecimento abre espaço ao que Jonas chamava de "consciência desmitologizada" (JONAS, Hans. Augustin und das paulinische Freiheitsproblem. Eine philosophische Studie zum pelagianischen Streit. Göttingen: Vandenhoeck \& Ruprecht, 1965, p. 82). O jovem Jonas explicita, por exemplo, que os dogmas do pecado original e da predestinação são "objetivações" de uma "experiência existencial concreta" (Idem, p. 88). Do mesmo modo, o gnosticismo foi interpretado à luz da analítica do Dasein elaborada por Heidegger em Sein und Zeit (1927). ${ }^{28}$ Como elucida Jonas, "por trás da desmitologização [tal como a entendia Bultmann] se encontra o imperativo da honestidade intelectual" (JONAS, Hans. Is Faith Still Possible? Memories of Rudolf Bultmann and Reflections on the Philosophical Aspects of His Work. Harvard Theological Review, 75, 1982, p. 1-23 [esp. p. 10]), que reza que todos os nossos atos envolvem uma relação de causa e efeito, ideia esta que nada mais é do que a expressão do famoso "axioma moderno da imanência", segundo o qual "uma lei natural [...] não tolera exceção alguma" (Idem) - nem mesmo a ação miraculosa de Deus.

${ }^{29}$ JONAS, Hans. Heidegger e a teologia. Revista de Filosofia, Aurora, Curitiba, v. 28, n. 43, p. 331-362, jan./abr. 2016, p. 360.
} 
tante "paradoxo final". Por isso, ao encerrar seu ensaio sobre Heidegger e o problema do conhecimento de Deus na teologia, conclui Jonas assim: “- o mito, considerado literalmente, é a objetivação mais grosseira. - O mito, considerado alegoricamente, é a objetivação refinada. - O mito, considerado simbolicamente, é o espelho no qual nos vemos obscuramente" ${ }^{\prime \prime}$. E é preciso que se entenda: esse "ver-se num espelho obscuramente" significa manter a opacidade manifesta do mito transparente para o inefável em detrimento da pretensa transparência do conceito.

Não é sem motivos, portanto, que Jonas se sirva de um mito de sua própria invenção para falar da aventura divina e assim dar conta desse episódio inigualável que é Auschwitz ${ }^{31}$, mito cujo valor (filosófico) caminha na direção da autorização platônica do recurso ao mito, que Jonas destaca como argumento para sua especulação sobre esse "não-objeto" (Deus) que, como tal, ultrapassa a esfera do conhecimento.

Esse, entretanto, é apenas um primeiro passo no distanciamento de Jonas em relação a Bultmann e Heidegger. Pois em um segundo momento, ele também passa a considerar como possível a "tradução da imagem em conceito"32. Esta informação que Jonas oferece em "The concept of God after Auschwitz" não busca outra coisa senão explicitar esse "passo adiante" de seu pensamento no que diz respeito à teologia (natural). A mudança de perspectiva fica claramente elucidado na seguinte afirmação do filósofo em seu ensaio sobre os aspectos filosóficos do pensamento de Bultmann:

"o fato de, nesta conferência ['Immortality and the Modern Temper'], ter recorrido a um mito simbólico - uma liberdade tomada a partir do exemplo de Platão - estava como tal já em desacordo com a rigorosa desmitologização de Bultmann, e a divergência foi por mim articulada ainda no final de 'Heidegger and Theology' [...] Mesmo depois, aventurei-me a tirar algumas conclusões desse 'mito' hipotético em termos de uma 'teologia' racional, dando, portanto, um passo adiante na trilha de uma doutrina 'objetiva' que Bultmann buscou evitar de forma profundamente instintiva"33.

Um "passo adiante" se dá, portanto, na passagem do recurso simbólico do mito para teologia racional, que se permite uma elaboração conceitual

\footnotetext{
${ }^{30}$ Idem, p. 361.

${ }^{31}$ A apresentação deste mito se encontra por primeira vez num artigo de 1962 (cf. JONAS, Hans Immortality and the Modern Temper. Harvard Theological Review 55, 1962, p. 1-20), em cuja ocasião o filósofo o aborda com o intuito de responder à questão específica da imortalidade. Este mesmo texto também aparece em The Phenomenon of Life: Toward a Philosophical Biology (Evanston: Northwestern University Press, 2001. p. 262-281). Mas também aí - afirma Jonas agora, por ocasião da elaboração do conceito de Deus - "o fantasma de Auschwitz também já se fazia presente" (CGA, p. 3). Jonas discute o problema inclusive com Bultmann (cf. JONAS, Hans. Zwischen Nichts und Ewigkeit: Zur Lehre vom Menschen. Göttingen: Vandenhoeck \& Ruprecht, 1963, p. 65).

32 JONAS, Hans. The concept of God after Auschwitz. Op. cit., p. 6.

${ }^{33}$ JONAS, Hans. Is Faith Still Possible? Op. cit., p. 22, n. 9.
} 
da própria imagem veiculada pelo simbolismo mítico. Isto, entretanto, não permite dizer, como o faz Nathalie Frogneux, que há uma "inflexão estritamente teológica do pensamento jonasiano", que "refere-se, sobretudo, ao fim dos anos 1970, e eminentemente ao livro O Princípio Responsabilida$d e^{\prime \prime 34}$. Pois fato é que uma tal mudança de perspectiva, ou nos termos de Frogneux, "inflexão", não vai de uma posição fenomenológico-existencial (ou mesmo hermenêutica) - de um período supostamente inicial do pensamento jonasiano - para uma postura metafísica tardia, como ela sugere; antes há que se observar que a mudança toda se encontra puramente no âmbito metafísico - onde "metafísico", neste caso específico, quer dizer "teológico" ${ }^{35}$. A inflexão de Jonas aí restringe-se, portanto, ao problema do conhecimento de Deus, a respeito do qual em contraposição à desmitologização bultmanniana ele passa de um elogio do recurso ao mito, de inspiração platônica, para uma postura especulativa, que se permite traduzir a linguagem mítica a partir da racionalidade conceitual filosófica.

De tudo isso, fica claro que o interesse de Jonas nesta tarefa de uma especulação teológica é fundamentalmente filosófico. Nesse sentido, em última instância é a reflexão racional que orienta a fé, e não o contrário. Contudo, não se pode aceitar que o intento jonasiano seja puramente filosófico ${ }^{36}$. Isto, entretanto, não é correto. Pois em uma entrevista concedida a Harvey Scodel, o próprio Jonas afirma claramente: "como uma pessoa religiosa, eu diria que Deus... tem um lugar em nossa existência" ${ }^{37}$. Mais ainda: em

\footnotetext{
${ }^{34}$ FROGNEUX, Nathalie. Hans Jonas ou la vie dans le monde. Bruxelles: De Boeck, 2001, p. 152.

35 Albrecht Wellmer percebeu bem essa diferença em Jonas no interior da tentativa de renovação da metafísica como tal: "a consciência crítico-conhecedora [erkenntniskritische Bewußtsein] acerca da transcendência de todo conhecimento possível nesta narrativa mítica está, em Jonas, conectada, portanto, com uma consciência crítico-lingüística [sprachkritischen Bewußtsein] acerca da inefabilidade - literal - daquilo que o mito tenta dizer. E não obstante, vejo uma certa tensão entre esta consciência lingüística acerca da inefabilidade daquilo que o mito está tentando dizer e sua tentativa, entretanto, de expressar isto filosoficamente. No que se refere ao primeiro elemento - consciência linguística acerca da inefabilidade daquilo que o mito está tentando dizer -, acredito que ele representa uma forma pós-kantiana, radicalizada, de metafísica crítica, tal como encontramos também nas reflexões críticas de Wittgenstein e Derrida sobre a linguagem. No que se refere ao outro elemento - a tentativa esforçada de Jonas em dar expressão filosófica ao conceitualmente inefável -, ele aponta para uma possibilidade - futura talvez - de preservar a metafísica kantiana ao mesmo tempo em que a ultrapassa. Duas possibilidades de ir além de Kant - e Hegel -, que, ao que creio, se excluem mutuamente" (WELLMER, Albrecht. Der Mythos vom leidenden und werdenden Gott: Fragen an Hans Jonas. In: Endspiele: die unversöhnliche Moderne: Essays und Vorträge. Frankfurt am Main: Suhrkamp, 1993, p. 250-56 [esp. p. 251]). Apesar de perceber essa dupla postura no interior da reflexão metafísica de Jonas, Wellmer não percebe, entretanto, que se trata de um "passo adiante" na posição jonasiana, e por isso, de maneira crítica, ele fala de uma "tensão" entre as duas posturas, enquanto duas possibilidades de ir além de Kant que se "excluem mutuamente".

${ }^{36}$ FROGNEUX, Nathalie. Une aventure cosmotheandrique: Hans Jonas et Luigi Pareyson. Revue-Philosophique de Louvain 100(3), 2002, p. 500-526 [esp. 504].

${ }^{37}$ JONAS, Hans. An Interview with Professor Hans Jonas (By Harvey Scodel). Social Research 70, n 2, Summer 2003, p. 339-68 [esp. 359]. Uma confessio deste tipo se encontra também na
} 
entrevista concedida para o Deutsche Zeitschrift für Philosophie, Jonas diz o seguinte a propósito de seu interesse ao escrever o ensaio The Concept of God after Auschwitz: "o que talvez haja de significativo nesse ensaio sobre o conceito de Deus depois de Auschwitz é apenas o esforço de conciliar as experiências passadas com certas representações da fé as quais não se gostaria de ter que renunciar" ${ }^{\prime \prime 38}$. Assim, embora o fundamental seja o aspecto teológico-filosófico, o aspecto propriamente religioso de maneira alguma está ausente. Este aspecto religioso terá inclusive, como veremos, uma importância fundamental na concepção propriamente filosófica de Jonas.

Desvelado esses elementos metodológicos que orientam a teologia especulativa jonasiana, podemos agora perguntar: qual é, então, o rosto de Deus tal como Jonas o concebe? A resposta só pode surgir com a elucidação do mito que Jonas cria para tal tarefa. Jonas começa seu mito expondo que o fundamento do ser, ou o Divino, ao criar, se aventura ao risco no seu próprio vir-a-ser, nada retendo de si. Deus assim se abstém de si mesmo, como um ser-no-mundo, lançado à imanência - "não no sentido de uma imanência panteísta" ${ }^{\prime 39}$, ressalta de antemão Jonas. E assim Deus o faz, despojando-se de seu ser próprio, de sua divindade, em favor do mundo, podendo mesmo ser desfigurado no decorrer do processo do universo. Feita essa consideração geral, Jonas então busca explicitar algumas etapas da aventura divina. Mais especificamente, Jonas elucida quatro momentos em que o ser de Deus se realiza ao lançar-se na odisséia do tempo. Em boa medida, essa odisséia é a narrativa do vir a ser do universo tal como pensado pela ontologia jonasiana elaborada em The phenomenon of live e em Organismus und Freiheit.

Primeiro, o filósofo explicita que por uma infinidade de tempos o ser de Deus se realiza nos torvelinhos da matéria que se acumulam como uma memória paciente nas mãos vagarosas da casualidade e da probabilidade cósmicas. É o que ele afirma ser uma "emergência hesitante de transcendência na opacidade da imanência" ${ }^{40}$.

entrevista de Jonas concedida a Herlinde Koebl: “o filósofo precisa levar a cabo seu próprio negócio, o pensar, de maneira totalmente livre de vínculos e pré-conceitos herdados. Ele está comprometido apenas com o pensar. A filosofia precisa ser 'ateística' no método. Isto não significa afirmar dogmaticamente que 'Deus não existe'. Mas significa não se permitir dizer nada desde a perspectiva de uma fé [religiosa]. Que se possa ser ao mesmo tempo filósofo e judeu - eis aí uma certa tensão da qual não há que se duvidar" (JONAS, 2013, p. 156).

${ }^{38}$ JONAS, Hans. Dem bösen Ende näher: Gespräche über das Verhältnis des Menschen zur Natur/ Hrsg. Wolfgang Schneider. Frankfurt am Main: Suhrkamp, 1993, p. 26. Em outro lugar Jonas também admite que seu ensaio sobre o conceito de Deus depois de Auschwitz foi uma contribuição nesse sentido: “Diferentemente do que acontece no caso dos milagres, aqui o judeu se encontra em maior dificuldade do que o cristão. Para o cristão, o mundo inteiro, de qualquer forma, jaz no maligno e é sempre um objeto de suspeita (o mundo humano em particular, por causa do pecado original); mas para o judeu, Deus é eminentemente o senhor da história; e como depois de Auschwitz o judeu crente deveria explicar para si mesmo o senhorio de Deus, e explicar como repensar o conceito tradicional de Deus, esse é seu angustiante problema hoje" (JONAS, Hans, Is Faith Still Possible? Op. cit., p. 17-18).

${ }^{39}$ JONAS, Hans. The Concept of God after Auschwitz. Op. cit., p. 4.

${ }^{40}$ Idem. 
Como segundo momento, encontramos o aparecimento da vida no seio do destino do mundo, como anseio divino pelo reencontro de sua plenitude. E "pela primeira vez - diz Jonas - Deus despertado pode dizer que a criação é boa" ${ }^{41}$. A vida falaria, assim, do que é bom. Mas com a vida - essa nova possibilidade do ser, como uma nova linguagem do mundo - vem a morte, um preço a ser pago, pois a vida é mesmo, para Jonas, "um ser essencialmente precário e corruptível, uma aventura na mortalidade" ${ }^{\prime 2}$. No entanto, é justamente essa pressão da finitude, que se estabelece sempre mais com o crescente despertar da consciência, o que permite o acesso da divindade à experiência de si mesma.

Cada nova resposta aberta no mundo enriquece a auto-experiência do fundamento divino do ser. Trata-se mesmo de um ganho do sujeito divino. E, como terceiro momento dessa colheita sempre mais rica da aventura divina, "o tesouro transcendente da eternidade temporalmente vivida" aumenta certamente com "o aparecimento do par percepção e movimento nos animais" ${ }^{33}$. Mais ainda: "suas criaturas, por meramente realizarem-se na busca [pursuit] de suas vidas, justificam a aventura divina" ${ }^{44}$. A aventura divina está neste estágio ainda salvaguardada, pois, "aquém do bem e do mal, Deus não pode perder no jogo da evolução" ${ }^{\prime 4}$.

Mas há ainda um último estágio. Aqui, Deus "estremece no momento em que um ímpeto da evolução, levado por seu próprio impulso, ultrapassa o limiar em que a inocência cessa e um critério de sucesso e fracasso inteiramente diferente toma posse da aposta divina" ${ }^{\prime 6}$. Trata-se do advento do sujeito humano, ser que traz consigo conhecimento e liberdade, e a ele agora cabe decidir sobre o bem e o mal ${ }^{47}$. Desse momento em diante, a "imagem de Deus" se vê em risco, pois se encontra ameaçada pela ação do homem, podendo "ser realizada, salva, ou arruinada pelo que ele fará a si mesmo e ao mundo" 48 . E, aqui, a imortalidade humana aparece como signo da "ideia de homem": cumprir a "ideia de homem" seria mesmo defender a "imortalidade humana", como veremos mais adiante. Deus sofre a partir daí os males de um ser preocupado, "esperando e torcendo, alegrando-se e entristecendo-se, aprovando e desaprovando - e, suponho

\footnotetext{
${ }^{41}$ Idem.

${ }^{42}$ Idem.

${ }^{43}$ Idem, p. 5.

${ }^{44}$ Idem.

${ }^{45}$ Idem.

${ }^{46}$ Idem.

${ }^{47}$ Aqui, Jonas oferece de maneira essencial o surgimento de uma problemática ética: " $\mathrm{O}$ advento do homem significa o advento do conhecimento e da liberdade, e com esse dom supremo, que é duplo, a inocência do mero sujeito de uma vida auto-realizada deu lugar ao desafio da responsabilidade sob a disjunção do bem e do mal" (Idem). No entanto, não podemos discorrer neste trabalho sobre as implicações éticas do mito jonasiano, problema que apenas deixaremos indicado.

${ }^{48}$ Idem.
} 
eu, fazendo-se sensível para ele [o homem], ainda que não intervindo na dinâmica de seu cenário mundano" ${ }^{\prime 4}$.

Tendo explicitado essa narrativa da aventura divina na odisséia do tempo, Jonas extrai as implicações teológicas que ela oferece, tentando mostrar ainda as ligações existentes entre o seu mito e a tradição judaica - conseqüências e ligações estas das quais ele afirma só ter tomado consciência lentamente. Em sua análise, Jonas tem sempre em vista um confronto com os atributos clássicos da divindade, a saber: a impassibilidade, a imutabilidade e a onipotência. Já no apontamento da primeira implicação teológica de seu mito, ele refere-se à ideia de um Deus sofredor. Ele diz que essa ideia contradiz a representação bíblica, pois particularmente na tradição cristã o sofrimento divino apenas se dá em um momento determinado, a encarnação e a crucificação, e com um objetivo também particular, a saber: o resgate do homem. Para Jonas, porém, se trata de um sofrimento que se inicia desde o instante da criação - principalmente do homem. E ele não parece considerar esta interpretação como totalmente inconciliável com a Bíblia, já que em sua defesa de um Deus sofredor, ele aponta para as imagens bíblicas de um Deus rejeitado pelo homem, e que ademais sofre com seu povo eleito, na medida em que este povo se faz esposa infiel. Não podemos, entretanto, dizer que tal ideia de um Deus sofredor se concilia com a noção grega de impassibilidade (que pensa cólera e desejo como não aplicáveis a Deus). O Deus sofredor de Jonas se angustia e se entristece com seu destino mundano; Ele é, por isso, como bem notou Robert Theis, "Deus passível, portanto Deus alterado" 50.

Disso, logo se entende uma segunda conseqüência que o mito jonasiano oferece: a imagem de um Deus em vir-a-ser ${ }^{51}$. Se a impassibilidade já não se aplicava ao conceito que Jonas tem em vista, muito menos se aplica a noção de imutabilidade - aqui, Jonas torna, inclusive, explícita sua contraposição

\footnotetext{
${ }^{49}$ Idem.

${ }^{50}$ THEIS, Robert. Dieu eclaté: Hans Jonas et les dimensions d'une théologie philosophique après Auschwitz. Revue Philosophique de Louvain 98(2), 2000, p. 341-357 [esp. p. 353].

${ }^{51}$ Também Scheler defendeu a ideia de um Deus em vir-a-ser e impotente. Embora alguns autores tenham enfatizado uma aproximação e mesmo plágio de Jonas em relação a Scheler, vale enfatizar que a ideia de um Deus em vir-a-ser e impotente já se encontra no gnóstico Marcião, que pode ter sido muito bem a fonte original para ambos os pensadores. No caso de Scheler, isso é facilmente comprovável. Ele cita Marcião: "Deus ou o impotente [Gott oder der Machtlose]" (SCHELER, Max. (1997). Gesammelte Werke, v. 15: Schriften aus dem Nachlass. Vol. VI: Varia II. Bonn: Bouvier Verlag, 1997, p. 163). E Jonas, como se sabe, é um especialista do gnosticismo, de modo que não se deveria esperar que este elemento de Marcião lhe tivesse passado despercebido, o que de fato não ocorreu, porque em seu ensaio sobre Bultmann, Jonas afirma explicitamente que a atitude de não se atribuir um governo constante do mundo à onipotência divina deve ser tomada "não por respeito às leis da natureza e da história, nem em razão da causa marcionita que afirmava que se importar com todo pardal que cai do céu estaria abaixo de Deus - mas antes porque coisas horríveis acontecem no curso do mundo e da história" (JONAS, Hans Wissenschaft als persönliches Erlebnis. Op. cit., p. 67 [grifo nosso]). Embora a ideia de Marcião não seja a razão, Jonas mostra conhecê-la.
} 
à tradição clássica. Ele afirma abertamente que sua concepção de um Deus em vir-a-ser contradiz a tradição grega e a teologia filosófica que foram incorporadas tanto pela tradição judaica quanto cristã. Para essa tradição clássica todo devenir é excluído do Ser puro, absoluto, da divindade. Para Jonas, entretanto, essa perspectiva não é autenticamente judaico-cristã, pois o pensamento helênico não cabe bem ao espírito e linguagem da Bíblia ${ }^{52}$. Como se pode ler em Êxodo 3: 14, no original hebraico, Deus responde a Moisés: Ehiê asher ehiê (היהא רשא היהא). Ehiê indica, no hebraico, a primeira pessoa do futuro do verbo Hayá, que é o mesmo que ser, estar, tornar-se. Assim, ehiê significa "eu serei". Portanto, a tradução da passagem inteira seria: "Eu serei o que serei", e não "Eu sou o que sou". Essa tradução mais usual, inclusive, demonstra o nível de influência que o pensamento grego exerceu no desenvolvimento teológico da tradição judaico-cristã. Se as conseqüências dessa alteração são infindas e nefastas, o que a passagem, no entanto, oferece à interpretação não é outra coisa senão a ideia de um Deus inominável ${ }^{53}$, um Deus não acabado totalmente ou completo, mas antes um Deus de possibilidades; um Deus que se fará o que o seu povo precisar; um Deus que não é imóvel, imutável, mas que antes é movimento incessante e se relaciona com seu povo, e em tudo está com ele em sua caminhada.

Nestes termos o conceito de Jonas se aproxima mais da linguagem propriamente bíblica, visto que seu Deus "se encontra afetado pelo que se passa no mundo, e 'afetado' quer dizer alterado, tornado diferente" Deus experiencia o mundo, está em relação com ele - esta é, inclusive, "a hipótese cardinal da religião" 55 lembra Jonas -, e isso quer dizer que "o Eterno se 'temporalizou' e torna-se progressivamente diferente através das atualizações do processo do mundo" ${ }^{\prime 56}$. Para que se entenda a radicalidade do que Jonas reclama para o seu conceito de Deus, basta destacar que ele chega mesmo a afirmar que a ideia de um Deus em vir-a-ser destrói a ideia nietzscheana de um eterno retorno do mesmo. E isso porque, o que retorna, ou se se preferir, o que torna a ocorrer nunca o faz da mesma forma; o que retorna nunca é o mesmo, pois "cada novo mundo a vir após o fim de outro", diz Jonas "carregará, como este era, em sua própria

\footnotetext{
${ }^{52}$ A origem dessa atitude de contraposição do Deus bíblico em relação ao Deus da filosofia remonta a Pascal (cf. ROMMEL, Herbert. Das Bedeutungsmoment des Geschichtlichen in der philosophischen Gottesrede bei Hans Jonas: eine Analyse aus transzendentaler Perspektive. Theologie und Philosophie, v. 81, n. 3, 2006, p. 400-412. p. 400).

${ }^{53}$ No hebraico o nome de Deus é um tetragrama: וזה-יה, o qual não apresenta vogais, mas apenas consoantes, e isso por dois motivos: (1) para que apenas os descendentes pudessem entender a linguagem de seu povo; e (2) para que o nome de Deus não fosse tomado em vão. Assim, atualmente não se sabe como o nome de Deus é verdadeiramente pronunciado, pois é constituído apenas de quatro consoantes: yhvh, e sua vocalização se perdeu com o passar do tempo.

${ }^{54}$ JONAS, Hans. The concept of God after Auschwitz. Op. cit., p. 7.

${ }^{55}$ Idem.

${ }^{56}$ Idem.
} 
herança a memória do que antes foi; ou em outras palavras, não existirá uma eternidade indiferente e morta, mas uma eternidade que cresce com a colheita acumulativa do tempo" ${ }^{\prime 57}$.

Tudo isto leva-nos à terceira conseqüência do mito de Jonas: este Deus sofredor e em vir-a-ser é, consequentemente, um Deus preocupado. Pois na medida em que ao criar o mundo, dispersando-se nele, em sua imanência, Deus se abre à existência do próprio mundo, estando com ele envolvido de uma vez por todas. Ora, e, se bem se está atento, é no caminho do processo evolutivo que Deus se realiza, e, no que lhe toca, a evolução é um processo de finitização no seio do próprio ser. Aqui, a encarnação do Logos - ainda que Jonas não utilize uma tal imagem - se faz uma boa analogia: Deus na sua plenitude se entrega a mais radical finitude. E esse é todo o risco divino, pois ao se abster de seu poder sobre o mundo, Deus se torna dependente dele - especificamente com o aparecimento do sujeito humano -, e vê-se constantemente exposto ao risco, ameaçado em sua integridade pelo que sua criação fará de tudo que lhe foi confiada, a saber, o ser em sua totalidade.

Como resultado final se explicita o que aos olhos de Jonas seria o ponto mais arriscado de seu conceito de Deus: "esse não é um deus onipotente!"58. Essa é a última e mais importante implicação teológica do mito de Jonas: Deus não é onipotente. Jonas ergue aqui dois argumentos. O primeiro é uma objeção lógica e ontológica à ideia de um Deus onipotente. Para Jonas, a própria ideia de onipotência é auto-contraditória, pois do mesmo modo que uma liberdade absoluta é vazia, também o é um poder absoluto. Um poder absoluto não pode ser e não é limitado por qualquer coisa que seja. A simples existência de algo exterior representaria já uma limitação. E a não presença, por sua vez, de um objeto exterior lança tal poder em tamanha solidão que se tornaria vazio por não poder dirigir-se a alguma coisa, o que não o permitiria sequer realizar-se. Em suma, o que Jonas destaca é que "potência como tal é um conceito relacional" 59, e como tal implica um objeto sobre o qual o poder incidiria, o que por sua vez seria ao mesmo tempo uma limitação, pois delimitaria sobre o que o poder deveria incidir.

O segundo argumento de que Jonas lança mão é uma objeção teológica, e aos seus olhos autenticamente religiosa: a onipotência divina só pode coexistir com a bondade divina se Deus for totalmente insondável, incompreensível, enigmático. O que mais explicitamente Jonas questiona é a compatibilidade entre os três reconhecidos (tradicionalmente) atributos de Deus: onipotência, bondade e compreensibilidade, pois para ele, esses três atributos "se fixam em uma tal relação lógica de um com o outro que

\footnotetext{
57 Idem.

58 Idem, p. 8.

${ }^{59}$ Idem.
} 
a conjunção de dois deles, quaisquer que sejam, exclui o terceiro" ${ }^{60}$. Ora, a vontade de fazer o bem é indissociável do conceito de Deus que ora Jonas defende - visto que a criação é boa; a ideia de um deus absconditus é inaceitável à tradição judaica, a qual o conceito de Jonas segue em muitas linhas: Deus é para essa tradição compreensível, e não um mistério obscuro. Se esses dois primeiros não podem faltar de modo algum ao conceito de Deus, só resta abandonar o terceiro dos atributos: a onipotência. Assim, Jonas justifica sua recusa da onipotência como atributo divino, pois - quase na via de um resumo de sua tese - "depois de Auschwitz, nós podemos afirmar, com maior força que antes, que uma deidade onipotente teria que ser ou não boa ou (na ordem do mundo, na qual apenas nós podemos o "observar") totalmente ininteligível" ${ }^{\prime 1}$. Aqui aparece a razão pela qual este conceito de Jonas é um conceito depois de Auschwitz. E a razão não é outra senão que Auschwitz representou a experiência do mal de uma forma tão terrível que a compreensibilidade de tal acontecimento não seria possível se imaginarmos que Deus, em sua absoluta bondade, o permitira, sendo todavia totalmente poderoso para impedi-lo. $\mathrm{O}$ único fato que poderia justificar tal acontecimento seria a não onipotência de Deus.

Não obstante, Vittorio Hösle dirigiu críticas aos argumentos de Jonas. Segundo Hösle, a crítica lógica de Jonas ao conceito de onipotência não se sustenta, pois para um ser intemporal a onipotência só pode ser concebida enquanto ação universal, e por isso, como já pensavam Leibniz e Spinoza, Deus não precisa intervir nas leis da natureza, porque Ele as criou ${ }^{62}$. Seguindo mais especificamente o sexto capítulo do Tractatus Theologico-Politicus de Spinoza, Hösle rejeita inclusive a tese de Jonas, segundo a qual Deus poderia intervir não nas leis da natureza, mas em situações em que elas não são determinadas ${ }^{63}$. A razão é simples: não só é impossível, mas supérfluo tal ação se se entende que a ação universal da criação já contempla tudo o que acontece posteriormente - embora não pense como Leibniz que esses dois fatores são completamente determinados pela razão de Deus. Por isso, embora a concepção jonasiana de uma dispersão de Deus em uma alteridade seja aceita por Hösle, já que sem esse recurso é difícil entender como o melhor dos mundos precisaria evoluir, ainda assim Hösle não aceita que tal dispersão seja arbitrária, pois a razão precisa estar presente e ser reconhecível. Nesse sentido, o mal moral deve ser tratado no mesmo sentido que Jonas trata a morte, que também é uma questão da teodiceia.

\footnotetext{
${ }^{60}$ Idem, p. 9.

${ }^{61}$ Idem, p. 9-10.

${ }^{62}$ HÖSLE, Vittorio. Theodicy Strategies in Leibniz, Hegel, Jonas. In: God as Reason: Essays in Philosophical Theology. Notre Dame, Indiana: University of Notre Dame Press, 2013, p. 50-74.

${ }^{63}$ HÖSLE, Vittorio. Ontology and Ethics in Hans Jonas. Graduate Faculty Philosophy Journal $23, \mathrm{n}^{\circ} 1,2001$, p. 31-50 [esp. p. 50, n. 46].
} 
Como se pode notar são duas críticas em uma só, e atacam os dois argumentos de Jonas. A diferença aí é resultado da forma como ambos os pensadores se posicionam em relação ao problema da causalidade. Em relação à parte final da crítica de Hösle, devemos dizer que também Jonas não aceita que o processo cósmico enquanto aventura divina seja um movimento puramente arbitrário: Jonas defende antes uma teleologia própria no interior da evolução cósmica, que embora não tenha desdobramento necessário, possui, entretanto, uma tendência, que apenas espera uma oportunidade para o seu aproveitamento dessa realização.

Do mesmo modo, a Hösle se pode fazer as mesmas críticas que antes Jonas dirigia já a Bultmann: antes de tudo, (1) a posição de Hösle está baseada em "uma concepção exagerada da estreiteza e rigidez da causalidade mundana" ${ }^{64}$, que acaba por fazer de qualquer introdução de uma causa não física uma laceração da rede causal dos eventos físicos. E mais importante, (2) uma tal posição se revela frágil para a causa da religião em geral, pois a concepção de Deus como uma mera causa primeira criadora do universo - ou mesmo sua concepção como um princípio transcendental estritamente lógico - se encontra no fato de que "admite apenas em princípio a ação de Deus em todas elas, mas exclui sua auto-revelação em eventos particulares. O ocultamento da transcendência, isto é, seu não aparecimento, é tão inviolável como o determinismo das coisas que aparecem" ${ }^{\prime \prime 5}$. Portanto, o que importa para Jonas é ainda pensar um Deus que faça sentido para o religioso, e nisso ele se embate com metafísica tradicional grega (e depois transposta para o mundo judaico-cristão). É também em função de uma postura religiosa, protestante em seu caso, que Heidegger rejeitou esse Deus da metafísica tradicional, posição esta que se conserva até um período tardio de seu pensamento, tal como se pode depreender do que ele diz na conferência "Identidade e diferença": "A este Deus não pode o homem nem rezar, nem sacrificar. Diante da causa sui, não pode o homem nem cair de joelhos por temor, nem pode, diante deste Deus, tocar música e dançar" ${ }^{\prime \prime 6}$.

É por isso que, como resultado, o mal não pode ser pensado simplesmente desde a mesma perspectiva que a morte - se não se aceita a premissa jonasiana de que em Auschwitz o mal encontrou uma expressão que até então não possuía. Auschwitz, como vimos no início deste trabalho, não aceita mais nenhuma metafísica de sucesso, tal como o determinismo pressuposto na crítica de Hösle torna necessário aceitar.

${ }^{64}$ JONAS, Hans. Is Faith Still Possible? Op. cit., p. 14.

${ }^{65}$ Idem.

${ }^{66}$ HEIDEGGER, Martin. Que é isto - A filosofia? Identidade e Diferença. Tradução de Ernildo Stein. São Paulo/Petrópolis: Vozes/Duas Cidades. 2006, p. 75. 


\section{A Ideia de um Deus não onipotente e o Fim da} Teodiceia

De tudo que dissemos até aqui, há que se notar que nas duas primeiras seções apresentadas, dois planos trabalhavam lado a lado para alcançar um objetivo derradeiro: responder ao problema da teodiceia, ou se se preferir, à sua principal questão: a questão de Jó. Cada um desses planos atende a um dos horizontes sob os quais Auschwitz pode ser pensado. $\mathrm{O}$ primeiro plano, que seria lógico-ontológico, visa responder a Auschwitz como acontecimento cosmológico, que não indica outra coisa senão a verdade do risco da aventura divina no mundo. Já o plano teológico pensa Auschwitz como acontecimento também teológico, achando-se relacionado à constatação de uma mal expresso numa radicalidade antes nunca vista.

Então, se Jonas, como vimos logo acima, salvava a bondade e compreensibilidade divinas em detrimento de sua onipotência, não representa isso uma escolha arbitrária pura e simplesmente. As consequências da imagem de Deus que o mito jonasiano oferece permitem responder tanto no plano lógico-ontológico, quanto teológico, à questão da teodiceia. Mais especificamente, o plano lógico-ontológico explicitado no mito de Jonas, que sustenta a imagem de um Deus, sofredor, em vir-a-ser, preocupado e impotente oferece os elementos para a resolução do problema do mal no plano teológico, ao pensar Deus como bom, compreensível, mas jamais onipotente. Assim, da mesma forma que a constatação de Auschwitz como acontecimento cosmológico levanta o enigma do silêncio divino como acontecimento teológico, as implicações teológicas do plano lógico-ontológico desvelado no mito jonasiano respondem ao problema da teodiceia como tal. E a resposta não é outra senão o fim da própria teodiceia inscrito na ideia de um Deus que já não é mais percebido como onipotente. Diante de Auschwitz, Deus não precisa mais de justificação; pois se evidencia que Ele nada podia fazer a respeito. Para Jonas, como bem exprime Amán R. Rodríguez, "o 'silêncio' de Deus durante os anos em que se consumou o holocausto deve ser tomado como um sinal de sua impotência, não de sua indiferença" ${ }^{\prime 67}$. Portanto, frente à principal questão da teodiceia, a questão de Jó, a conclusão de Jonas "é contrária àquela dada pelo livro de Jó: esta, para uma resposta, invocou a plenitude do poder de Deus; a minha, [invocou] seu escolhido esvaziar-se deste [poder]" ${ }^{\prime 68}$. Em suma, $o$ conceito de Deus que Jonas apresenta face ao acontecimento de Auschwitz ergue a não onipotência como atributo da divindade e representa o fim da teodiceia. Pois,

\footnotetext{
${ }^{67}$ ROSALES RODRÍGUEZ, A. Hans Jonas, 'El concepto de Dios después de Auschwitz' y su relación con la idea de un pensamiento posmetafísico, Areté, XV (2), p. 267-302, 2003, p. 281. A seguir mostraremos, entretanto, que deve-se evitar o uso do termo "impotência" para o Deus jonasiano, devendo-se, antes, falar de simples não onipotência, já que Deus não esvazia completamente a possibilidade da ação de Deus em sua criação - especialmente no homem. ${ }^{68}$ JONAS, Hans. The Concept of God after Auschwitz. Op. cit., p. 13.
} 
como se vê, Jonas não atende mesmo a todos os requisitos - notadamente o primeiro requisito - que Paul Ricoeur destacava como característicos e necessários para a constituição propriamente de toda teodiceia: aqui já não se tenta conciliar as três premissas Deus é bom, Deus é onipotente, o mal existe; antes se diz: Deus é bom, e o mal existe, pois Deus é impotente. Eis aí por que já não se precisa justificá-lo face à existência do mal, o que constitui o fim da teodiceia propriamente. Podemos dizer até mesmo que ao decretar o fim de toda teodiceia, a empresa jonasiana é ela própria a última teodiceia, já que torna desnecessária qualquer outra teodiceia.

Mas uma questão de grande ímpeto deve ser ressaltada para que o conceito jonasiano de Deus possa ser pensado em toda sua peculiaridade e profundidade: qual seria o grau de ingerência de Deus no curso da história? Seria total? Ou, antes, parcial? Total seria, por exemplo, a resposta de Olivier Boulnois. Para ele, a análise de Jonas, inspirada pela cabala, nos remeteria ao seguinte dilema: "nós temos que escolher entre um Deus providente e sádico ou um Deus bom e impotente" ${ }^{69}$, onde "impotente" significaria a impotência total. Mas poderíamos aceitar uma tal leitura acerca do que Jonas pensa quando se refere à não onipotência divina? Certamente que não. No entanto, justamente o equívoco de Boulnois ilumina o caminho que se deve percorrer para delimitarmos mais exatamente o que está implicado na relação entre o fim da teodiceia e a não onipotência divina.

Mas antes disso, faz-se necessário rebater primeiro a própria ideia de uma intervenção e influência parcial de Deus no mundo. De fato, uma posição muito frequente a esse respeito é aquela que tenta salvar a potência divina, afirmando que Deus é onipotente, mas que abdica apenas temporalmente de seu poder em favor de sua criação. Deus teria, portanto, o poder, mas o empregaria apenas em determinados momentos especiais. Note-se, entretanto, que isso Jonas não pode aceitar, pois, pode-se perguntar: que evento mais terrível poderia fazer com que Deus quebre sua regra de controle e intervenha com um milagre salvífico senão este que atende pelo nome de Auschwitz? Se Deus não impediu tamanho mal é porque não o podia fazer. E nesse sentido, Jonas se afasta dos mais antigos ensinamentos judaicos. Em especial, se afasta diretamente de Maimônides, cujos vários artigos de fé ressaltam a "mão poderosa" de Deus ${ }^{70}$. Ademais, a simples admissão da liberdade humana já envolveria, para Jonas, uma certa renúncia ao poder divino. O silêncio em Auschwitz pode ser visto,

${ }^{69}$ BOULNOIS, Olivier. The Concept of God After Theodicy. Communio 29, 2002, p. 444-468 [esp. p. 458].

${ }^{70}$ Como bem observa Philippe Ivernel, tradutor francês do livro de Jonas sobre o conceito de Deus depois de Auschwitz, a ideia de "mão poderosa" como imagem da onipotência divina se encontra em Maimônides exatamente como sucedâneo de uma leitura alegórica do "El Chaddaï", a qual toma por base categorias gregas (em especial, aristotélicas) (cf. JONAS,Hans. Le Concept de Dieu après Auschwitz: une voix juive. Trad. Philippe Ivernel. Paris: Éditions Payot \& Rivages, 1994. p. 42n). 
portanto, como uma confirmação factual radical tardia da contradição lógica e do princípio da liberdade humana.

E é assim, portanto, que para Jonas diante dessa recusa da onipotência divina resta apenas duas escolhas teóricas: a assunção de um dualismo preexistente, que seria ou bem teológico ou ontológico; ou a admissão da auto-limitação de Deus em sua creatio ex nihilo. Jonas rejeita as respostas dualistas (maniqueísta e platônica) ao problema, e afirma que "somente com a criação do nada temos a unidade do princípio divino combinado com a auto-limitação que então permite (dar 'lugar' a) a existência e a autonomia de um mundo"71 - a criação sendo o ato (único) de soberania absoluta de Deus, e, ao mesmo tempo, um ato de desapoderamento divino. Assim se realiza o recurso jonasiano a uma reflexão cosmogônica alternativa em que se verifica a possibilidade de se pensar o poder de renúncia de Deus em favor da autonomia cósmica e de suas possibilidades ${ }^{72}$.

Apesar disso, Jonas salienta ainda que a origem de seu conceito se relaciona com a Cabala, corrente que integra a tradição judaica, mas que de maneira não ortodoxa também "conhece um destino divino submisso ao vir-a-ser do mundo"73. Jonas diz mesmo que seu mito é uma radicalização da ideia de Tzimtzum (contração, dispersão, auto-limitação), conceito cosmogônico da Cabala luríaca (isto é, criada por Isaac Luria). Como dissemos, trata-se de uma radicalização, pois, ao contrário da contração divina local que encontra-se na Cabala, para Jonas a "contração" divina é total, e isto quer dizer que depois de "ter ele se dado todo ao vir-a-ser do mundo, Deus não tem mais nada a dar: é o homem agora que deve lhe retribuir"74. Agora cabe ao homem ajudar a Deus, e não o contrário.

Como se vê, Jonas recorre a tradição da Cabala, que tem grande relação com algumas inspirações gnósticas, nas quais mais especificamente se encontra, inclusive, como bem lembra Robert Theis, a ideia de "dispersão", da qual Jonas faz uso em seu mito ${ }^{75}$. E justamente aí incide o equívoco de Olivier Boulnois que salientávamos acima. Porque se Boulnois destaca a relação do conceito de Jonas com a Cabala não é por outro motivo senão o de demarcar a impotência como marca de um total afastamento de Deus em relação ao mundo. $\mathrm{O}$ que se teria aí seria um Deus que responderia por uma exterioridade absoluta, lançado mesmo à pura ociosidade. Ora, isso se aplica também ao gnosticismo - claro, com suas nuances próprias. Nesse ponto, inclusive, o equívoco de Boulnois se torna ainda mais visível, porque ao expor a teologia gnóstica, Jonas destaca o fato de Deus ser

\footnotetext{
${ }^{71}$ JONAS, Hans. The Concept of God after Auschwitz. Op. cit., p. 11.

72 Cf. JONAS, Hans. Materie, Geist und Schöpfung. Op. cit., p. 55-59.

${ }^{73}$ JONAS, Hans. The Concept of God after Auschwitz. Op. cit., p. 12.

${ }^{74}$ Idem.

75 THEIS, Robert. Dieu eclaté. Op. cit., p. 353.
} 
pensado aí como um ser "auto-contido e distante"76, justamente o contrário do que Jonas reclama intencionalmente para a imagem do Deus que ora ele evoca em seu mito: "um Deus não distante, separado e auto-contido, mas envolvido com o que ele se importa"77.

Não obstante, ironicamente, está claro que o mito jonasiano se arrisca também, a uma primeira vista, a ser interpretado a partir da prefiguração de um próprio panteísmo - é por isso, inclusive, que Jonas, de antemão, explicita a falsidade dessa possibilidade na própria apresentação de seu mito, como o mostramos. E, aqui, há que se pontuar: é por Deus "ter renunciado ser "tudo em tudo"' que ele renuncia a sua onipotência em favor do próprio agir do que criara. Disso resulta que a ideia de um Deus onipotente se adequa mais ao panteísmo, pois uma vez que Deus é onipotência ele é também o poder de ação de toda ação, e portanto de tudo que é ação, o que seria dizer que ele se confundiria com o mundo, lugar de toda ação - os entes finitos sendo apenas uma expressão da substância infinita.

Como bem percebeu Cristina Beckert, "o mais surpreendente, nesta narrativa [de Jonas], é que não nos deparamos nem com um Deus que se recolhe em si mesmo depois do primeiro impulso criador, à maneira deísta, nem, inversamente, com uma identificação plena dele com o mundo, à maneira panteísta"78. E isso é assim, primeiro, porque Deus em "seu próprio ser é afetado pelo que acontece nele"79. A divindade como que assume $^{80}$ a diversidade ontológica em cada momento de seu vir-a-ser. Não é sem motivos que da metafísica esboçada simbolicamente em seu mito Jonas diga que "resultam algumas conclusões éticas", pois o que está em jogo aí é a importância transcendente de nosso agir, já que nossas vidas "se tornam marcas na face divina" ${ }^{81}$. E, de fato, um dos grandes pontos da análise jonasiana da shoah, como bem percebeu Nathalie Frogneux, é mostrar que o sofrimento não apenas afeta as vítimas impotentes daquele ato hediondo, mas se inscreve num plano transcendente; o próprio Deus sofre $^{82}$. Portanto, este aspecto transcendente de nosso agir nos torna não

\footnotetext{
${ }^{76}$ JONAS, Hans. The Gnostic Religion: the message of the alien god and the beginnings of christianity (1958). Boston: Beacon Press, 1972, p. 42.

77 JONAS, Hans. The Concept of God after Auschwitz. Op. cit., p. 7.

${ }^{78}$ BECKERT, Cristina. Teologia depois da Shoah: a crítica de Hans Jonas à Teodiceia. Revista Portuguesa de Filosofia, 57, 2001, p. 733-744 [esp. p. 737].

${ }^{79}$ JONAS, Hans. The Concept of God after Auschwitz. Op. cit., p. 7.

${ }^{80}$ Trata-se de um problema de extrema complexidade, uma vez que Deus não se confunde com o mundo, mas engendra em si os próprios "elementos" do que cria, ao criar mesmo. E isso é assim porque o que Deus é não pode se confundir com sua criação, porque senão a criação se tornaria antes duplicação.

${ }^{81}$ JONAS, Hans. The Phenomenon of Life: Toward a Philosophical Biology. Evanston: Northwestern University Press, 2001, p. 278.

${ }^{82}$ La souffrance humaine maximisée en Dieu: une lecture du mythe de Hans Jonas. Revista da Faculdade de Letras, Filosofia, Universidade do Porto, v. XX, 2003, p. 125-140 [esp. p. 131].
} 
apenas responsáveis pelo mundo, mas pelo próprio Deus ${ }^{83}$. É nesse sentido que o filósofo afirma que o "homem não foi criado tanto 'à' imagem quanto 'para' a imagem de Deus" ${ }^{\prime 84}$. Assim, o efeito produzido por - ou se se preferir: a colheita de - nossas ações padece de uma ambiguidade terrível: sob nossas mãos a imagem de Deus é construída ou destruída, levada a sua plenitude ou deformada. Esta é a conclusão ética da imortalidade de nossos atos, os vestígios que deixam para trás. Mas as marcas deixadas se estabelecem não no destino do próprio indivíduo, que é temporário e efêmero. Embora fiduciária mortal de uma causa imortal, cada pessoa é apenas uma aposta do eterno, de modo que o resultado permanece sempre em aberto, a ser sempre novamente decidido ${ }^{85}$. O valor da história coletiva sobrepuja o próprio indivíduo humano, cujo valor moral só se eleva enquanto responsável pela humanidade, isto é, faz-se imortal, na medida em que ele já não age por si, mas em função da preservação da imagem do humano.

Mas se Deus é afetado pelas ações humanas, isto não significa que a ele pertence apenas uma posição de passividade na relação com o destino humano de sua criação. Este resultado seria tão pouco interessante desde uma perspectiva religiosa como aquele deísmo da modernidade. Assim, que o homem seja feito para a imagem de Deus não significa, como pensa Frogneux, que Deus seja "somente o testemunho transcendente da torpeza e da solidariedade humanas, dos eventos históricos, a garantia da medida e da justeza dos fatos face às observações ou memórias, individuais e coletivas, frágeis"86. Deus não é um mero epifenômeno; não é a mera consciência inefectiva da história. Aqui, Frogneux pensa que a pura passividade de Deus ${ }^{87}$ é afirmada para que o bem não seja confundido com o mal, bem como para não contradizer "o espírito moderno da imanência total da sorte mundana e humana"88. Mas já vimos que Jonas não se deixa levar por uma aceitação rígida desse axioma moderno da imanência. É por

\footnotetext{
${ }^{83}$ É interessante notar que tal como acontece em seu Das Prinzip Verantwortung, Jonas identifica uma nova dimensão da responsabilidade humana, não apenas pelo futuro distante, mas por Deus. Na verdade, como revela em "Immortality and the modern temper", trata-se de uma mesma responsabilidade, já que, em última instância, a causa divina está em risco justamente com a possibilidade de destruição da humanidade.

${ }^{84}$ JONAS, Hans. The Phenomenon of Life. Op. cit., p. 278.

${ }^{85} \mathrm{~A}$ imortalidade, tal como Jonas a concebe em seu ensaio "Immortality and the modern temper" (1962), não pode ser pensada para a existência humana individual, mas apenas para a existência humana entendida enquanto uma coletividade Isto se confirma de maneira mais explícita em outro lugar (cf. JONAS, Hans. Erkenntnis und Verantwortung: Gespräch mit Ingo Hermann in der Reihe "Zeugen des Jahrhunderts". Hrsg. Von Ingo Hermann. Göttingen: Lamuv, 1991, p. 144-45).

${ }^{86}$ FROGNEUX, Nathalie. La souffrance humaine maximisée en Dieu. Op. cit., p. 133.

${ }^{87}$ Frogneux sugere mesmo que, segundo Jonas, Deus se reduziu voluntariamente "a uma passividade total, ele não age, mas faz memória da atividade humana ao deixá-la se inscrever nele" (Idem [grifo nosso]).

${ }^{88}$ Idem.
} 
isso também que, para ele, a relação entre Deus e homem não precisa ser pensada estritamente como unilateral. Ela não tem no homem a sua causa, e em Deus, seu efeito; mas também possui a direção inversa, de Deus para os homens. A relação entre Deus e homem reduplica, por assim dizer, a relação que no homem há entre mente e corpo ${ }^{89}$. Mas como pode ser isso se já se afirmara anteriormente sua não onipotência?

Ora, , em relação a nova alternativa teológica que Jonas oferece, é preciso que se entenda, por fim, que embora, "por um tempo - o tempo do contínuo processo do mundo -", Deus tenha se desinvestido "de qualquer poder para interferir fisicamente no curso das coisas" ${ }^{10}$, isso não pode apagar o fato de que, como diz Jonas, a "impotência de Deus se refere apenas ao domínio físico" ${ }^{\prime \prime}$. Porque, para Jonas, não se invalida a ideia do chamado de Deus às almas, nem muito menos sua unidade e com ela o "Ouça, ó Israel". Explicitamente, demonstram sobremaneira esse "chamado às almas" as palavras que Jonas encontrara no diário de Etty Hillesum, uma jovem judia, que se apresentou como voluntária para ajudar nos campos de concentração em Auschwitz:

“Eu devo tentar ajudá-lo, Deus, a impedir que minha força se esvaeça, embora eu não possa responsabilizar-me muito mais por ela. Mas uma coisa está se tornando incrivelmente clara para mim: que o Senhor não pode nos ajudar, que nós devemos ajudar o Senhor a nos ajudar... Infelizmente, ali não parece que o senhor mesmo possa fazer algo sobre nossas circunstâncias, sobre nossas vidas. Nem posso eu afirmar que és responsável. O Senhor não pode nos ajudar, mas nós devemos ajudar o Senhor e defender sua morada em nós até o fim"'"'92.

Assim, que no conceito jonasiano de Deus esteja inscrito o fim da teodiceia não significa que Deus tenha voltado seu rosto contra os homens, afugentando-se em uma morada distante e escondida, pois ele ainda se faz ouvir como força aos que buscam defender sua morada no seio da plenitude do ser - o que seria o traço verdadeiro da eternidade e imortalidade humanas.

Depois deste longo percurso que percorremos, gostaríamos de ainda apontar, por fim, para duas fragilidades dessa teologia especulativa que Jonas desenvolve como resposta a Auschwitz. Antes de tudo, não devemos negar que a clara diferença da concepção de Jonas para o deísmo se fixa no fato de que o Deus jonasiano não se retira do mundo, mas

\footnotetext{
${ }^{89} \mathrm{O}$ próprio Jonas parece sugerir isto quando em seu ensaio sobre Bultmann sugere uma analogia entre a ação divina e a potência da subjetividade no mundo (cf. JONAS, 1987b, p. 55-63; 1982, p. 10-15). E um dos pontos fundamentais no que defende Jonas aí é a crítica a uma rígida defesa do axioma da imanência na ciência moderna.

${ }^{90}$ JONAS, Hans. The Concept of God after Auschwitz. Op. cit., p. 10.

${ }^{91}$ Idem, p. 11 [grifo nosso].

${ }^{92}$ Idem, p. 13n.
} 
experiencia o seu desenrolar, uma vez que o criara a partir de si mesmo, de seu próprio seio. Também fica claro que isto não cai num panteísmo que facilmente identifica Deus e o mundo. A solução de Jonas parece ser outra; parece reclamar o que se pode designar por panenteísmo, isto é, a afirmação de que "toda a realidade está, de maneira inexplicável e misteriosa, 'em Deus"' ${ }^{\prime \prime 3}$. Deus não seria assim transcendente ao mundo, mas transcendente na imanência do mundo mesmo ${ }^{94}$ Trata-se, portanto, de afirmar uma transcendência na imanência. Apesar disso, um curioso problema parece ficar sem explicação na meditação metafísica de Jonas sobre o seu Deus sofredor. Haja vista que em seu The phenomenon of life o próprio Jonas afirmara a impossibilidade de um Deus matemático não poder conhecer a vida orgânica tal como o pode o homem, já que àquele falta o corpo do qual este pode ter experiência, pode-se perguntar, junto com Frogneux, "como Deus poderia perceber, entretanto, o sofrimento humano se ele não conhecesse nada da encarnação da carne e do corpo?" Duas possibilidades apenas parecem disputar a resposta: ou Deus não é uma mera imagem passiva do que acontece a sua criação, e assim precisa de algum modo possuir certos atributos próprios à vida que ele criou; ou Deus conhece a realidade corporal e a atividade para além de sua passividade. Esta disjunção revela a dificuldade que o pensamento jonasiano ainda conserva para a resolução do rebelde problema psicofísico, pois na medida em que recusa o panteísmo de tipo spinozista, e na medida que tampouco age sobre o físico, o Deus de Jonas deixa em aberto a própria possibilidade da relação entre matéria e espírito, e a integração entre transcendência e imanência se torna enigmática.

Além dessa primeira fragilidade, outra ainda acena. A afirmação do homem como ponto final não é apenas uma afirmação ontológica, mas visa responder também a questão ético-existencial. Nesse sentido, ao pedir que o homem seja preservado do destino de um museu paleontológico, ela exige não apenas uma reflexão ética fundamental capaz de mostrar a maior razoabilidade do dever-ser da humanidade, mas pretende também dar uma resposta à questão do sentido da existência humana desde a renovação do conceito de imortalidade, que como tal busca também oferecer uma resposta ao problema ético. Não podemos seguir esse problema aqui em toda sua extensão, mas tentaremos iluminar o que está em jogo. A imortalidade representou para a tradição uma grande resposta ao problema do sentido da vida. Mesmo em Kant, o agir por dever se mostrou como insuficiente, porque deixa sem resposta a pergunta do sentido da existência. Que sentido

\footnotetext{
${ }^{93}$ CASTRO, Manuel Cabada. El Dios que Da que Pensar. Madrid: Biblioteca de Autores Cristianos, 1999, p. 438.

${ }^{94}$ A ideia de panenteísmo já se encontra mesmo no que, ao seguir o poeta Arato, afirma São Paulo: "nele vivemos, e nos movemos, e existimos" (At. 17: 28).

${ }^{95}$ FROGNEUX, Nathalie. La souffrance humaine maximisée en Dieu. Op. cit., p. 135.
} 
tem agir moralmente, se isso afasta o homem da felicidade individual? Os postulados da razão prática parecem oferecer uma tentativa de resposta a esse problema, e nesse sentido reafirmam que ao pensar não deve ser negado o impulso a conjecturar sobre as questões metafísicas últimas: a existência de Deus, a imortalidade, etc.

Jonas segue esse impulso em direção à resposta do sentido da existência humana. Mas ele não postula mais uma alma individual imortal. A imortalidade só pode ser pensada em relação ao coletivo; só à humanidade cabe a imortalidade. E a decisão temporal (individual e coletiva) de preservação dessa humanidade no futuro é o caminho de estabelecimento dessa imortalidade. É essa a sugestão de Jonas no ensaio "Imortality and the modern temper". Mas o que concede a essa ação preservadora o papel de garantir o sentido da existência? Por que ela afirma o valor último e absoluto da própria existência da humanidade? É aqui mais propriamente que o problema aparece em todo o seu sentido. Como é possível justificar esse valor absoluto da humanidade? Naturalmente, é a esta questão que o maior esforço de Das Prinzip Verantwortung foi dirigido. Não tratamos aqui da fundamentação metafísica de Jonas. Deixamos essa empresa para uma ocasião futura. Mas é fácil perceber que um grande número de questões se abre diante de nós no que concerne a este ponto. Ao buscar fundamentar metafisicamente a diferença antropológica enquanto diferença ética, Jonas consegue, por acaso, desvencilhar-se da ideia de um Deus omnibondoso? Albrecht Wellmer percebeu este problema, e o próprio Jonas reconheceu que não se pode escapar-lhe facilmente. Mais: além desse problema levantado por Wellmer (ao qual Jonas dá uma resposta mínima em sua carta para Bultmann, ao defender o mal como necessário, embora não na direção que os estoicos buscaram conceber essa necessidade), também o problema do sentido da existência humana fica sem resposta - e justamente quando este era um dos pontos de partida da filosofia jonasiana, isto é, a superação do niilismo. De fato, não se pode deixar de perguntar a Jonas como a ação moral pode, em última instância, dar uma resposta para o sentido da existência humana ao reduzir o conceito de imortalidade para o campo da coletividade apenas? A esse respeito, a resposta de Jonas parece ser ainda menos aceitável do que a de Kant. Esta questão se agrava se tivermos em mente que os dados cosmológicos de que dispomos até o momento anunciam para daqui a alguns milhões de anos a morte da Terra e, posteriormente, a morte do próprio Sol, que irá se tornar uma anã branca. Jonas tinha consciência desse evento, e se limitou certa vez a dizer que até lá, isto é, até que esse evento fatal ocorra, muito se poderia fazer aqui na Terra, de modo que não precisamos nos preocupar. Essa, entretanto, é uma resposta insatisfatória do ponto de vista filosófico. Mesmo a resposta de que o fim trágico do sistema solar não é, de fato, uma questão propriamente ética, já que ela não envolve a ação humana, não satisfaz à questão do sentido e valor da existência humana como tal. 
Estaríamos, aqui, então diante da dura realidade de que nos informara outrora Nietzsche: a saber, que o homem é um animal que não deu certo? ${ }^{96}$.

Aqui, voltamos à questão acima salientada: um Deus omnibondoso poderia ainda ser resposta suficiente para o problema do sentido da vida diante de uma situação como a que agora nos encontramos? Jonas não tinha, de fato, uma resposta para essa questão. Tudo isto, entretanto, não deve apagar o poder de seu pensamento. Um pensar que não deixou outra coisa senão um esforço inestimável de oferecer uma nova via de acesso ao sentido da existência. Sua resposta era, por fim, uma de tipo extremamente pessoal, e buscava animar sua própria coragem e disposição para defender o valor de um mundo no qual ele não se sentia um estranho e estrangeiro, mas em casa. Não um mundo inóspito, mas acolhedor. E, talvez, tenha sido mesmo esse o maior de todos os esforços da biologia filosófica deste grande filósofo alemão: desvelar o mundo como uma verdadeira morada humana, e o homem, outrora desenraizado, ciente de seu enraizamento e o único responsável por si e pela própria natureza que o produziu.

\section{Bibliografia}

BECKERT, Cristina. Teologia depois da Shoah: a crítica de Hans Jonas à Teodiceia. Revista Portuguesa de Filosofia, 57, 2001, p. 733-744.

BOULNOIS, Olivier. The Concept of God After Theodicy. Communio 29, 2002, p. 444-468.

BULTMANN, Rudolf. (1960[1941]). Neues Testament und Mythologie. Das Problem der Entmythologisierung der neutestamentlichen Verkündigung (1941). In: BARTSCH, H.-W. (Hrsg.): Kerygma und Mythos, Band 1, 4. Auflage. Reich, Hamburg 1960.

CASTRO, Manuel Cabada. El Dios que Da que Pensar. Madrid: Biblioteca de Autores Cristianos, 1999.

DOMINGUES, Ivan. Técnica, Ciência e Ética. Kriterion, Belo Horizonte, no 109, Jun/2004, p. 159-174.

FONTI, Diego. Del Mal (contra toda teodicea). Nombres, n 17, dec. 2002, p. 137-150.

FROGNEUX, Nathalie. Hans Jonas ou la vie dans le monde. Bruxelles: De Boeck, 2001.

. Une aventure cosmotheandrique: Hans Jonas et Luigi Pareyson. Revue-Philosophique de Louvain 100(3), 2002, p. 500-526.

\footnotetext{
${ }^{96}$ Aqui apenas elaboramos muito livremente o importante problema que Ivan Domingues (Técnica, Ciência e Ética. Kriterion, Belo Horizonte, no 109, Jun/2004, p. 159-174., p. 173-174) levantou para a ética jonasiana.
} 
. La souffrance humaine maximisée en Dieu: une lecture du mythe de Hans Jonas. Revista da Faculdade de Letras, Filosofia, Universidade do Porto, v. XX, 2003, p. 125-140.

HEIDEGGER, Martin. Que é isto - A filosofia? Identidade e Diferença. Tradução de Ernildo Stein. São Paulo/Petrópolis: Vozes/Duas Cidades. 2006.

HÖSLE, Vittorio. Ontology and Ethics in Hans Jonas. Graduate Faculty Philosophy Journal 23, $\mathrm{n}^{\circ} 1,2001$, p. 31-50.

- Grandezas y Limites de la Filosofia Moral de Kant. In: El tercer mundo como problema filosofico y otros ensayos. Bogota: CEJA, 2003, p. 69-95.

. Theodicy Strategies in Leibniz, Hegel, Jonas. In: God as Reason: Essays in Philosophical Theology. Notre Dame, Indiana: University of Notre Dame Press, 2013, p. 50-74.

JONAS, Hans. (1965[1930]). Augustin und das paulinische Freiheitsproblem. Eine philosophische Studie zum pelagianischen Streit. Göttingen: Vandenhoeck \& Ruprecht, 1965.

. (1972[1958]). The Gnostic Religion: the message of the alien god and the beginnings of christianity (1958). Boston: Beacon Press, 1972.

. (1962). Immortality and the Modern Temper. Harvard Theological Review 55, 1962, p. 1-20.

(1963). Zwischen Nichts und Ewigkeit: Zur Lehre vom Menschen. Göttingen: Vandenhoeck \& Ruprecht, 1963.

. (2001[1966]). The Phenomenon of Life: Toward a Philosophical Biology. Evanston: Northwestern University Press, 2001.

(1982). Is Faith Still Possible? Memories of Rudolf Bultmann and Reflections on the Philosophical Aspects of His Work. Harvard Theological Review, 75, 1982, p. 1-23.

. (1984[1979]). Das Prinzip Verantwortung: Versuch einer Ethik für die technologische Zivilisation. Frankfurt am Main: Suhrkamp, 1984.

. (1987). The Concept of God after Auschwitz: a Jewish voice. The Journal of Religion, v. 67, $\mathrm{n}^{\circ} 1,1987$, p. 1-13.

. (1987). Wissenschaft als persönliches Erlebnis. Göttingen: Vandenhoeck \& Ruprecht, 1987.

. (1988). Materie, Geist und Schöpfung. Frankfurt: Suhrkamp, 1988.

. (1994). Le Concept de Dieu après Auschwitz: une voix juive. Trad. Philippe Ivernel. Paris: Éditions Payot \& Rivages, 1994.

. (2010). Matéria, espírito e criação. Trad. de Wendell E. Soares Lopes. Petrópolis: Vozes, 2010.

. (1993). Dem bösen Ende näher: Gespräche über das Verhältnis des Menschen zur Natur/ Hrsg. Wolfgang Schneider. Frankfurt am Main: Suhrkamp, 1993.

. (2003) An Interview with Professor Hans Jonas (By Harvey Scodel). Social Research 70, n 2, Summer 2003, p. 339-68. 
(2003). Erinnerungen: Nach Gesprächen mit Rachel Salamander. Frankfurt am Main: Insel Verlag, 2003.

. (2013). Kritische Gesamtausgabe der Werke von Hans Jonas, B. III/2: Herausforderungen und Profile Jüdisch-deutscher Geist in der Zeit - gegen die Zeit. Hg. v. Sebastian Lalla, Florian Preußger und Dietrich Böhler .Freiburg i. Br./Berlin/ Wien: Rombach, 2013.

. (2016). Heidegger e a teologia. Revista de Filosofia, Aurora, Curitiba, v. 28, n. 43, p. 331-362, jan./abr. 2016.

LEVINAS, Emanuel. Sin Nombre. Diálogo Filosófico 43, 1999, p. 27-30.

REA, Caterina. Retrait de Dieu et question du mal. Une lecture éthique du mythe de Hans Jonas. Revue Philosophique de Louvain 100(3), 2002, p. 527-548.

RICHARDSON, William J. Heidegger and God - and Professor Jonas. Thought 40, $\mathrm{n}^{\circ} 156,1965$, p. 13-40.

RICOEUR, P. Le Mal: un défi à la philosophie et à la théologie (1986). In: Lectures 3: Aus frontières de la philosophie. SJ. Ed. Seuil, Paris, 1994, 211-233.

ROMMEL, Herbert. Das Bedeutungsmoment des Geschichtlichen in der philosophischen Gottesrede bei Hans Jonas: eine Analyse aus transzendentaler Perspektive. Theologie und Philosophie, v. 81, n. 3, 2006, p. 400-412.

ROSALES RODRÍGUEZ, A. Hans Jonas, 'El concepto de Dios después de Auschwitz' y su relación con la idea de un pensamiento posmetafísico, Areté, XV (2), p. 267-302, 2003.

SCHELER, Max. (1997). Gesammelte Werke, v. 15: Schriften aus dem Nachlass. Vol. VI: Varia II. Bonn: Bouvier Verlag, 1997.

SCOTT, Charles R. Heidegger reconsidered: a response to professor Jonas. Harvard Theological Review, 59:2 (1966):p. 175-185.

SÈVE, Bernard. Hans Jonas et l'Éthique de la Responsabilité. Esprit, novembre, 1990, p. $72-88$.

THEIS, Robert. Dieu eclaté: Hans Jonas et les dimensions d'une théologie philosophique après Auschwitz. Revue Philosophique de Louvain 98(2), 2000, p. 341-357.

WELLMER, Albrecht. 1993. Der Mythos vom leidenden und werdenden Gott: Fragen an Hans Jonas. In: Endspiele: die unversöhnliche Moderne: Essays und Vorträge. Frankfurt am Main: Suhrkamp, 1993, p. 250-56.

Endereço do Autor:

Rua Luís Antônio de Figueiredo 112 - Apto. 903

Bairro Jardim Petrópolis

78070090 Cuiabá - MT

wendellsoareslopes@gmail.com 